\title{
REAKTUALISASI PENDIDIKAN KARAKTER DI ERA DISRUPSI
}

\author{
Sayyidi \\ Sekolah Menengah Kejuruan (SMK) Syarifuddin Lumajang, Indonesia \\ Email : sayyidi.4040@gmail.com \\ Muhammad Abdul Halim Sidiq \\ Institut Agama Islam Syarifuddin Lumajang, Indonesia \\ Email : dulhalim2528@gmail.com
}

\begin{abstract}
Perkembangan pendidikan selalu berubah seiring perkembangan zaman, semakin luas akses interaksinya semakin luas pula tantangannya. Anak yang di didik di masa lalu kini menghadapi tantangan nyata saat ini, sementara anak yang di didik saat ini suatu saat akan berhadapan dengan tantangan masa depan. Transformasi pendidikan memang menjadi sebuah keharusan yang tak terhindarkan guna mengimbangi arus dirupsi. Pendidikan di masa lalu cukup mudah membuat anak menjadi pribadi yang taat patuh dan mudah diatur meskipun fungsi tripusat pendidikan berjalan timpang dan lebih memerankan pendidikan dilingkungan sekolah. Akan tetapi hasilnya sudah cukup memuaskan dalam membentuk karakter dan kepribadian anak yang baik, berbeda dengan kondisi saat ini dimana peran lingkungan pendidikan keluarga dan masyarakat harus mulai diperankan secara maksimal.

Kondisi ini merupakan imbas era dirupsi yang tidak bisa dibendung, tidak hanya pola pikir siswa yang terkontaminasi oleh pemikiran "merdeka belajar" sesuai asumsi dan persepsi mereka, guru pun sudah mulai tertular 'virus-virus' pemikiran matrealistik yang ditularkan oleh dunia dirupsi. Pendidik, orang tua, dan masyarakat perlu memahami pentingnya tranformasi pendidikan yang berbasis karakter, pendidikan yang membentuk kepribadian profesional, mandiri, dan islami.

Untuk mewujudkan impian pendidikan karakter perlu adanya kesadaran belajar dan mengajar. Pendidik harus mengubah mindset dalam mengajar, mengubah pola dan kebiasaan dilingkungan sekolah, keluarga, dan masyarakat, dengan tujuan mereka bisa terlibat aktif, pendidik perlu mencari cara, memikirkannya dan mengkombinasikan nilai-nilai islam dan budaya lokal. Keterlibatan pendidik di tiga lingkungan di atas diyakini akan mampu menetralisir rayuan negatif yang ditimbulkan oleh kecanggihan globalisasi. Sehingga Pendidikan bisa diartikan upaya transformasi ilmu pengetahuan (transfer of knowledge), pengayaan nilai (transfer of value), pengetahuan tentang karakter kebudayaan (transfer of culture), dan penanaman nilai keagamaan (transfer of religius) menuju orientasi pola perubahan perilaku individu agar memiliki nilai-nilai luhur, cerdas dan terampil.
\end{abstract}

Kata Kunci : Pendidikan Karakter, Guru, Dirupsi, Belajar. 


\section{Pendahuluan}

Pendidikan dan pembelajaran merupakan aktifitas kehidupan manusia yang tidak dibatasi ruang dan waktu. Pendidikan dan pembelajaran dapat berjalan secara terstruktur atau tidak (formal dan non formal). Jalur pendidikan formal merupakan aktifitas pembelajaran terencana, terprogram berbentuk klasikal berjenjang, dan berijazah. Sementara yang non formal lebih bersifat insidental, tidak terencana, tidak dibatasi ruang dan waktu, tanpa guru dan pemandu dengan media handphone atau tablet, di luar maupun di kelas. Sebagaimana di maksud dalam UU nomor 20 tahun 2003, pada pasal 1 ayat 1 disebutkan bahwa:

"Pendidikan adalah sebuah usaha yang di lakukan secara sadar dan terencana untuk mewujudkan suasana belajar dan proses pembelajaran agar peserta didik secara aktif mengembangkan potensi dirinya untuk melihat kekuatan spiritual keagamaan, membangun kepribadian, pengendalian diri, kecerdasan, akhlak mulia, serta ketrampilan yang diperlukan dirinya, masyarakat, bangsa dan Negara." 1

Undang-undang 'sisdisknas' yang terdiri dari 77 pasal tersebut tertandatangani pada 8 Juli 2003 oleh presiden RI, Megawati Soekarnoputri dan diundangkan di Jakarta oleh Sekretanis Negara RI, Bambang Kesowo.

Berbicara soal pendidikan ada tiga lingkungan pendidikan yang perlu mendapat dukungan secara penuh, lingkungan sekolah yang relatif terorganisir dengan sebuah sistim telah berperan dalam batasan kurikulum baku dan standar, akan tetapi jika melihat peran lingkung pendidikan keluarga sejauh mana para orang tua memainkan perannya? Belum lagi berbicara peran lingkungan masyarakat dalam membentuk karakter dan kepribadian kolektif pada masyarakat tertentu, di lain sisi belum lagi adanya intervensi dirupsi yang berkembang pesat menyuguhkan informasi yang lebih menggoda dengan kecanggihan teknologi yang tidak bisa dibendung. Kunci utama pendidikan adalah

\footnotetext{
${ }^{1}$ Komisi Informasi Pusat Republik Indonesia, UU Nomor 20 Tahun 2003 tentang Sistem Pendidikan nasional, https:/ / komisiinformasi.go.id/?p=1638 (diakses 01 Maret 2020)
} 
pembentukan karakater dan intelektualitas. Selaras dengan Djoko Saryono, bahwa pembentukan karakter dan intelektual menjadi visi, misi dan tujuan pendidikan di manapun, kapanpun, dan dilaksanakan oleh siapapun. ${ }^{2}$ Selama ini pendidikan lebih fokus pada bagaimana karakter anak didik, sedangkan penguatan karakter pendidik masih jarang diperbincangkan.

Dominasi intelektualitas pendidik terhadap anak didik seakan akan mematikan dan menafikan potensi anak didik, asumsi seperti ini yang seharusnya menjadi keseriusan pemangku kebijakan dan kepentingan mengubah mindset dan budaya pendidikan era melenial. Disadari atau tidak, bahwa dalam dunia pendidikan terdapat arus transformasi pendidikan timbal balik antara pendidik dengan yang di didik, pendidikan dan pengajaran secara harfiah memiliki kesamaan tujuan akan tetapi ada perbedaan cakupan, mengajar merupakan proses transformasi keilmuan dari tidak tahu menjadi tahu, dari tidak faham menjadi faham, dari tidak mengerti menjadi mengerti. Dalam Islam, tradisi transformasi tradisi keilmuan merupakan dokrin dalam agama yang sudah dicontohkan oleh Rasulullah Saw., ${ }^{3}$ dan dikembangkan para cendekiawan secara dinamis sesuai dengan perkembangan zaman. baik sejak masa khulafaur Rasyidin dan dinasti Muawiyah, pendidikan Islam terus eksis bahkan mencapai masa kejayaan transformasi keilmuan dalam semua bidang pada dinasti Abbasiyah, baik ilmu agama maupun ilmu umum. Menurut K. Ali dalam Mashuri, pendidikan berlangsung di berbagai tempat seperti; rumah pribadi, istana, took-toko buku, masjid, maktab,

\footnotetext{
2Djoko Saryono, "Kaum Muda, Pembentukan Karakter dan Intelektualitas, dan Peran Budaya Lokal pada Abad Pengetahuan." Journal of Intensive Studies on Language, Literature, Art, and Culture, 2017, Dari International Proceedings; International Seminar on Language, Literature, Art and Culture (ISLLAC), Malang, September 26-27, 2017. ${ }^{3}$ Mashuri, S. Transformasi Tradisi Keilmuan Dalam Islam: Melacak Akar Kemunculan Dan Perkembangan Institusi Pendidikan Islam. HUNAFA: Jurnal Studia Islamika, 4(3), 227-236. 2007. https://doi.org/https://doi.org/10.24239/jsi.v4i3.215.227-236
} 
bait al-hikmah, perpustakaan dan yang monumental kemunculan madrasah-madrasah. ${ }^{4}$

Sedangkan mendidik tidak hanya sekedar arus transformasi keilmuan melainkan terdapat proses internalisasi nilai-nilai pengetahuan kedalam pola pikir dan perilaku siswa sehari hari. Saatnya para pendidik berinovasi dan berkreasi membangun komitmen dan memahami program "merdeka belajar" dan "merdeka mengajar". Seperti yang telah diagendakan pemerintah melalui Menteri Pendidikan dan Kebudayaan, yang dituangkan dalam blue print program pendidikan nasional. ${ }^{5}$ Selama kita mau, dengan hati yang sabar dan tawakkal guru akan tetap digugu dan ditiru, selama masih punya nafas untuk memperbaiki perbaikilah, rasa pesimis ubahlah menjadi optimis, mindset negatif ubahlah menjadi mindset positif. Sebagaimana yang dilakukan para cendekiawan muslim masa keemasaan, bahwa tempat kediaman para ulama' pun menjadi bagian dari lembaga pendidikan (non formal). Disanalah para pendidik tersebut meneladankan karakter Islam secara kuat dalam semua proses pendidikan dan pembelajaran. Semua pendidik memiliki peran yang penting dalam menanamkan pendidikan karakter. Karena pendidiklah keteladanan pendidikan karakter itu akan diteladani semua peserta didik.

\section{Pembahasan}

\section{Trasnformasi Pendidikan Karakter}

Pendidikan merupakan kegiatan belajar mengajar, salah satunya dalam menata kehidupan sehari-hari, belajar merupakan hal yang signifikan untuk ditekuni, dengan tujuan untuk mampu mengembangkan dan membuka potensi diri menjalani kehidupan yang sarat dengan rintangan dan persaingan. Sebagai subyek pendidikan, manusia dalam

\footnotetext{
${ }^{4}$ Mashuri, S. Transformasi tradisi keilmuan dalam islam: melacak akar kemunculan dan perkembangan institusi pendidikan islam. 2007.

5 Asri Kusuma, Dewanti, "Roadmap atau Blue Print Pendidikan Nasional 2020." Arsip Publikasi Ilmiah Biro Administrasi Akademik, 2020.
} 
belajar bisa memanfaatkan berbagai media, sarana, dan lingkungan belajar yang nyaman baik formal, informal maupun non formal. Lingkungan belajar formal dikenal dengan istilah lembaga pendidikan formal sebagaimana jenjang pendidikan yang ada di Indonesia, yaitu tingkat dasar, menengah, hingga perguruan tinggi. Tranformasi pendidikan karakter diintegrasikan di berbagai level pendidikan yang ada, agar pendidikan karakter benar-benar mengakar kuat di semua komponen pendidikan. ${ }^{6}$

Lembaga pendidikan formal memiliki peran dan fungsi sebagai penjamin mutu pendidikan (quality assurance of education). Sistem penjamin mutu pendidikan formal sudah diatur secara internal maupun eksternal. Sistem penjaminan mutu internal bisa dilakukan dengan langkah Plan, Do, Chek dan Act, pengembangan silabus, penentuan KKM, penentuan standar kelulusan (SKL), supervisi pembelajaran dan evaluasinya. Sehinnga mutu internal pendidikan mampu menggapai prstasi baik skala nasional maupun international. ${ }^{7}$ Demikian halnya, peningkatan mutu siswa bisa dilakukan dengan pemenuhan sarana dan prasana, utamanya lembaga formal berbasis sekolah menengah kejuruan. Diperlukan upaya optimal dalam proses perencanaan, penggunaan, dan pengawasan infrastruktur yang harus ada untuk mencapai kualitas lebih baik. ${ }^{8}$ Sementara lembaga pendidikan non formal lebih dikenal dengan istilah lingkungan belajar, ada lingkungan keluarga, lingkungan masyarakat. lingkungan ini lebih diposisikan sebagai pengawasan mutu pendidikan (quality supervision of education).

\footnotetext{
${ }^{6}$ Akbar K. Setiawan, Integrasi Pendidika Karakter dalam pembelajaran berbasis intercultural, Jurnal Pendidikan Karakter, Tahun 1, Nomor 1, Oktober 2011, 110-118. ${ }^{7}$ Darmaji dkk., Sistem Penjaminan Mutu Internal Sekolah di Satuan pendidikan Dasar, JPDN: Jurnal Pendidikan Dasar Nusantara, Volume 5 Nomor 2, Januari 2020. ttps://doi.org/10.29407/jpdn.v5i2.13190

${ }^{8}$ Yulius, Mellky. "Strategi Meningkatkan Mutu Pendidikan Melalui Manajemen Sarana Dan Prasarana Pada Smk Negeri 1 Singkawang." KHAZANAH PENDIDIKAN 13.2 (2020).
} 
Bapak pendidikan Ki Hajar Dewantara, jauh sebelum kita lahir telah mempopulerkan istilah tripusat pendidikan; pendidikan dilingkungan keluarga, lingkungan sekolah, dan lingkungan masyarakat. ${ }^{9}$ Sementara saat ini posisi pendidikan yang berperan aktif sebatas lingkungan sekolah, bisa dimaklumi karena posisinya sebagai lembaga yang menjamin mutu pendidikan, sementara lingkungan keluarga dan masyarakat masih terkesan pasif, jika ada mungkin hanya sebagian saja yang aktif, bagaimana cara guru membangunkan mati surinya kedua lingkungan tersebut agar ikut ambil peran dalam pembentukan karakter anak.

Dalam dunia pendidikan keluarga, orang tua adalah ujung tombak proses transformasi pendidikan di lingkungan rumah tangga, baik tidaknya seorang anak adalah tanggungjawab orang tua. Namun hal ini bukan berarti justifikasi bahwa seorang anak harus selalu menuruti kehendak orang tua, karena juga tidak sedikit orang tua kadang justru memberikan arahan yang kurang baik menurut norma yang ada, baik norma hukum, norma agama, norma kesusilaan, ataupun norma kesopanan. Nah, di sinilah diperlukan "konsolidasi" antara anak dan orang tua, agar bisa saling memberi dan menerima, dari sana akan tercipta suasana yang kondusif dalam sebuah keluarga. Jika memang ada permasalahan dalam keluarga maka bisa dibicarakan secara baik-baik dengan anak bersangkutan, supaya anak tersebut bisa memahami terhadap kemungkinan potensi diri yang dipendamnya.

Peran orang tua dalam mendidik anaknya memiliki cara yang berbeda-beda dan tanpa kita sadari, sebenarnya bukan hanya anak saja yang belajar, tetapi kita juga belajar kepada anak sebab kedewasaan berfikir orang tua bisa tumbuh setelah mendapat persoalan persoalan keluarga yang ditimbulkan oleh anak dan boleh jadi kita dalam

\footnotetext{
9 Suparlan, Henricus. "Filsafat pendidikan Ki Hadjar Dewantara dan sumbangannya bagi pendidikan indonesia." Jurnal Filsafat 25.1 (2015): 56-74.
} 
memperlakukan anak lebih banyak dipengaruhi oleh apa apa yang telah dilakukan orang tua kita semasa kecil, seakan-akan terkesan ada motif balas dendam. Dalam membentuk karakter yang baik dibutuhkan lingkungan yang baik pula, ada lembaga pendidikan islam ada beragam jenis sekolah formal baik jalur kementerian agama maupun kemendikbud seperti madrasah Ibtidaiyah, madrasah Tsanawiyah, dan madrasah Aliyah, di pondok pesantren ada SMP, SMA, dan SMK dan sejenisnya. Pendidikan pesantren representasi pendidik memiliki keberperanan kuat dalam transmisi pendidikan karakter. ${ }^{10}$ Tranforamsi pendidikan karakter dipesantren memiliki keunikan dengan variannya seperti adanya sekolah model pesantren, sekolah terpadu, sekolah integratif, sekolah berasrama dan lain lain.

Islam sebagai agama yang rahmatan lil-alamin diyakini mampu menciptakan lingkungan yang baik walau hakekatnya semua agama mengajarkan kebaikan tetapi al-Quran telah banyak menggambarkan bahwa lingkungan yang baik akan mampu mendatangkan kebaikan sebagaimana dijelaskan penduduk suatu kaum yang berbuat kebaikan akan mendapatkan keamanan dan kedamaian. ${ }^{11}$ Sebaliknya lingkungan yang dipenuhi dengan keburukan atau kedurhakaan akan mendapatkan malapetaka sebagaimana al-Quran jelaskan bahwa penduduk suatu kaum yang selalu berbuat durhaka akan mendapatkan siksa. ${ }^{12}$

Pentingnya nuansa islami tidak hanya menciptakan budaya cerdas sehat berkarakter akan tetapi akan mampu membentuk kedamaian kolektif diseluruh lapisan masyarakat, tebentuk proses interaksi efektif inovatif yang didukung oleh lingkungan tarbiyah islamiah sebagai modal menuju percepatan pendidikan. Sebagai lingkungan tarbiyah islamiah, ia

\footnotetext{
${ }^{10}$ Mundiri, Akmal, and Irma Zahra. "Corak Representasi Identitas Ustadz dalam Proses Transmisi Pendidikan Karakter di Pesantren." Jurnal Pendidikan Islam Indonesia 2.1 (2017): 21-35.

${ }^{11}$ Al-Qur'an ..Q.S. 16:112

12 Al-Qur'an..Q.S. 4:75; 7:4; dan 17;16.
} 
memiliki fungsi antara lain menunjang terjadinya proses kegiatan belajar mengajar secara aman, tertib, dan berkelanjutan. ${ }^{13}$

Keterlibatan keluarga dan masyarakat merupakan keniscayaan untuk membangun pendidikan karakter, mungkin saja apatisme masyarakat dipicu oleh kebijakan politik pendidikan yang top down atau mungkin saja pihak sekolah atau guru belum pernah diajak urun rembuk bersama memecahkan persoalan pendidikan yang berbasis karakter. Berbagai peraturan perundang-undangan bidang pendidikan yang ditetapkan pada era otonomi daerah, khususnya UU no 12 tahun 2003 tentang sistim pemdidikan nasional, menegaskan pergeseran paradigma pendidikan nasional dari education for all (pendidikan untuk semua) ke education from all, by all, and for all (pendidikan dari semua, oleh semua, dan untuk semua). Paradigma pertama memang membuka lebar-lebar akses pendidikan pada semua lapisan masyarakat, namun perencanaan, penyelenggaraan, dan pengevaluasiannya sangat didominasi oleh pemerintah dan pendanaanya tergantung pada subsidi pemerintah. ${ }^{14}$

Kebijakan pendidikan yang terkesan dominatif ini tanpa disadari akan memicu apatisme masyarakat terhadap percepatan pendidikan, jika memang pendidikan untuk semua lebih arif dan bijaksana jika semua dilibatkan, kurikulum belum tentu mampu mengatasi semua persoalan pendidikan, jika kurikulumnya sudah sesuai kondisi lembaga tertentu mungkin gurunya masih perlu dipertanyakan, jika gurunya sudah hebat adakah yang bisa menjamin aspek perilaku siswa diluar sekolah bisa terkontrol?. Keterlibatan keluarga dan masyarakat untuk aspek kepribadian dan perilaku seharusnya menjadi fokus utama pendidikan, ada banyak buku yang menawarkan pendidikan karakter cuma perlu diketahui, buku hanyalah buku sebatas pengetahuan, sementara karakter butuh pembentukan, disekolah pembentuknya adalah guru kelebihannya

\footnotetext{
${ }^{13}$ Lihat Abuddin Nata, Filsafat Pendidikan Islam (Ciputat: PT Logos Wacana Ilmu, 1997), 112

${ }^{14}$ Lihat M. Sirozi, Politik Pendidikan, ( Jakarta : PT Raja Grafindo Persada, 2005), 220
} 
guru dalam menjalankan tugas didukung oleh peraturan serta pembiasaan di lingkungan sekolah, saat diluar sekolah siapa yang menjamin guru dibenarkan apabila menegur anak diluar sekolah? apakah akses guru mampu menjangkau ke lingkungan keluarga dan masyarakat? Ini tugas utama dalam memaksimalkan peran tripusat pendidikan.

\section{Rekonstruksi Mindset Mendidik}

Belajar adalah rasa ingin tahu terhadap hal yang belum diketahui, rasa ingin tahu ini tumbuh dan muncul dari kesadaran manusia melalui proses aktifitas kegiatan sehari hari, kesadaran manusia dari tidak tahu menjadi tahu adalah proses belajar yang dipengaruhi apa yang didengar dan dilihat. Dalam konteks itulah diperlukan adanya pola pendidikan yang tidak terjebak oleh rasa tendensius dan tidak memperhatikan kepentingan peserta didik. ${ }^{15}$

Guru tugasnya bukan membentuk anak didik sesuai dengan keinginannya melainkan guru berkewajiban menggali potensi dan bakat yang ada pada diri si terdidik, mengarahkan tumbuhnya potensi potensi positif yang dimiliki serta menetralisir potensi-potensi negatif yang dimungkinkan tumbuh pada diri anak, untuk itu selayaknya pemangku kepentingan harus berusaha memahami aspek kekuatan (strength) dan kelemahan (weakness) sebagai faktor dominan dalam membentuk kepribadian anak. Selain adanya faktor bawaan dan hidayah. ${ }^{16}$ Modal utama yang menjadi kekuatan dalam pendidikan adalah kemampuan fisik (jasmani) yang dapat melakukan apa saja dan kemampuan non fisik (ruhaniah) baik intelektual maupun spiritual.

\footnotetext{
${ }^{15}$ Mahsun, M., \& Koiriyah, M. 2019. Meningkatkan Keterampilan Membaca Melalui Media Big Book Pada Siswa Kelas Ia Mi Nurul Islam Kalibendo Pasirian Lumajang. Bidayatuna: Jurnal Pendidikan Guru Mandrasah Ibtidaiyah, 2(01), 60-78. http://ejournal.iaisyarifuddin.ac.id/index.php/bidayatuna/article/view/361 ${ }_{16}$ Ali Lestari, Pandangan Islam tentang factor pembawaan dan Lingkungan dalam pembentukan Manusia; kajian ilmu pendidikan islam, Jurnal Pendidikan UNIGA, Volume 5, Nomor 1, 2011.
} 
Di lain sisi aspek kelemahan yang harus dijaga dari kedua faktor ini adalah potensi negatif yang diolah melalui informasi lingkungan sekitar dan timbul hasrat mencoba untuk melakukannya, kelemahan ini yang perlu diwaspadai oleh para pendidik. Dengan kelengkapan jasmaniahnya, ia dapat melaksanakan tugas tugas yang memerlukan dukungan fisik, dan dengan kelengkapan rohaninya, ia dapat melaksanakan tugas tugas yang memerlukan dukungan mental.

Selanjutnya agar kedua unsur tersebut dapat berfungsi dengan baik dan produktif, maka perlu dibina dan diberikan bimbingan ${ }^{17}$. Disamping itu guru juga perlu mewaspadai faktor ancaman (threat) dari luar dan mempertimbangkan faktor yang menjadi peluang (oportunity) terhadap perkembangan pendidikan anak. Ancaman pendidikan yang paling sulit diatasi adalah faktor internal biasanya. Hal ini berawal dari rasa kurang peduli terhadap gejala gejala yang muncul dalam perkembangan anak, dibiarkan begitu saja tanpa ada tindakan preventif, tidak melaporkan gejala-gejala tersebut kepada pihak yang berwenang atau sharing dengan rekan rekan guru untuk mengatasinya. Sehingga disaat terjadi perubahan yang drastis sampai mencoreng nama baik sekolah mereka saling lepas tangan dan acuh terhadapat persoalan yang terjadi.

Potensi ancaman sangat berpeluang untuk terjadi, karena seorang pendidik yang memahami situasi dan kondisi ditemukan ancaman, sehinggga berupaya untuk menetralisir dengan mencari alternatif peluang yang mungkin bisa dilakukan sebagai solusi, perinsipnya kalau tidak bisa mencegah setidaknya ada upaya untuk mengalihkan agar berimbang, Hartomo dalam bukunya mengatakan "saya bermaksud mengubah problem ini menjadi suatu kesempatan", pandangan masa depan dengan

${ }^{17}$ Abuddin Nata, Filsafat Pendidikan......, 35. 
pemecahan dari diri sendiri, sebagia tujian menjadi batu loncatan untuk mendapat sebuah pengalaman baru, atau pemecahan kreatif ${ }^{18}$.

Guru kreatif dan inovatif akan selalu berupaya menemukan terobosan baru dengan inovasi yang inspiratif. Guru produktif transformatif akan berupaya mewujudkan impian peserta didik dalam sebuah karya nyata membentuk karakter dan kepribadian peserta didik yang mandiri dan berprestasi. Intinya, menurut Akmal, Guru pada masa ini diharapkan menjadi figur yang mampu mengelola program pembelajaran menggunakan metode yang tepat, dan sesuai dengan kebutuhan peserta didik. Guru hendaknya memiliki kompetensi kepribadian yang berkharisma, berwibawa, dan bijaksana dalam menghadapi peserta didik untuk dijadikan sebagai teladan baik. ${ }^{19}$

Keberhasilan seseorang dalam bekerja tergantung pada benar tidaknya paradigma seseorang tentang kerjanya, Seorang guru yang selalu menyimpulkan bahwa muridnya bodoh, dia pasti terpengaruh oleh asumsinya itu sehingga proses belajar mengajarnya (KBM) di kelas tidak efektif dan tidak maksimal, sebab dia menganggap dengan metode apapun dalam mengajar siswanya tidak mungkin mampu, daripada repot repot mencari berbagai metode pembelajaran, maka dicarinya cara sederhana dan alami saja. Dengan sentuhan sedikit saja dianggapnya lebih dari cukup. Akibatnya paradigma yang salah, muridnya akan selalu bodoh sebab gurunya malas melakukan terobosan ${ }^{20}$.

Mari berfikir sejenak, disaat bayi baru lahir, ia menagis tanpa ada yang mengajari cara menangis mungkin inilah yang disebut dengan ilham

\footnotetext{
${ }^{18}$ Hartomo, Manajemen potensi diri, membangun motivasi dan mencetak prestasi unggul, kreatif, inovatif, dan produktif, (ttp: Platinum, 2013), 52.

${ }^{19}$ Akmal Mundiri dan Afidatul bariroh, Amplifikasi Profesi Guru dalam Proses Pendidikan Transformatif Perspektif Al-Ghazali, Jurnal Ilmiah Islam Futura, Vol. 18, No.1, Agustus 2018.

${ }^{20}$ Lihat Suharyo dan Soejitno Irmim, 7 Langkah memperbaiki diri, pedoman efektif untuk memperbaiki perilaku menuju kesempurnaan diri (ttp : Syima Media, tt), 69.
} 
dari sang pencipta atau petunjuk kebenaran dari Ilahiyah. ${ }^{21}$ Tangisan ini bertujuan mengajari orang-orang di sekelilingnya terutama ibunya agar segera bertindak dan berbuat yang seharusnya. Saat si bayi berumur satu tahun, ia mulai belajar berjalan walau jatuh bangun berkali-kali, namun ia tidak pernah putus asa termasuk keluarganya, dan akhirnya diapun bisa berjalan bahkan berlari cepat. Mengapa? yang jelas karena ia selalu berusaha dan tidak putus asa. Dia yakin bahwa jika mencoba dan mencoba akan berhasil, apalagi orang tua di sekitarnya selalu memberikan dukungan penuh sebagai wujud motivasi extrinsik.

Setiap keberhasilan yang diraih selalu disambut dengan kegembiraan oleh si anak sehingga terpacu untuk meraih kesuksesan. Demikian pula anak yang berumur dua tahun, ia mulai belajar berbicara, melafalkan setiap huruf dari kata yang tidak jelas menjadi jelas dari tidak fasih menjadi fasih dan seterusnya. Siswa juga demikian butuh dampingan seorang guru, guru dituntut peka terhadap kondisi siswa, memahami karakternya, menganalisa potensinya, mempetakan kemampuannya, serta mendeteksi bibit bibit potensi negatif yang terbentuk karena faktor genetika maupun karena faktor tekanan lingkungan, hal ini bertujuan untuk membentuk kepribadian dan karakternya dalam menghadapi sebuah persoalan, jika subyek dan obyek pendidikan saling memahami dengan kondisi masing masing maka akan terbangun sinergitas potensi intrinsik dan extrinsik dalam sebuah proses pendidikan. Untuk menciptakan budaya pendidikan yang berkarakter diperlukan adanya sinergi sekolah dengan rumah antara guru dan orang tua serta lingkungan sekitar, hakekatnya pendidikan karakter tidak banyak membutuhkan biaya, yang dibutuhkan adalah komitmen, konsekuen, dan konsisten dari semua pemangku kepentingan ${ }^{22}$. Yang

\footnotetext{
${ }^{21}$ Mahfud Junaedi, Paradigma Baru Filsafat Pendidikan Islam, (Depok: Kencana, 2017), cetakan ke-1, 93

${ }^{22}$ Lihat Najib Sulhan, Panduan praktis Pengembangan Karakter dan Budaya Bangsa, sinergi sekolah dengan rumah, (Surabaya : Jaring Pena, 2011), 28.
} 
menjadi pertanyaan apa saja upaya pemangku kebijakan dan kepentingan dalam menanamkan suasana belajar yang harmonis-demokratis dalam lingkungan keluarga sementara kebanyakan dari mereka lebih sibuk mementingkan kerja.

Pada saat si kecil sudah beranjak usia masuk ke bangku belajar di tingkat Pendidikan Anak Usia Dini (PAUD) atau sekarang lebih dikenal dengan istilah Kelompok Belajar (KB) sang guru selalu melatih untuk memperkenalkan dirinya sendiri baik secara fisik maupun non fisik ia tanyakan; ini siapa? ini apa namanya? ini apa gunanya?, ia latih bernyanyi, ia ajari bergerak, dan ia rangsang segala potensi dirinya sampai menjelang ke tingkat pendidikan Taman Kanak Kanak (TK) kemudian si anak masuk kelas satu di tingkat dasar atau madrasah ibtidaiyah, dalam proses pembelajaran biasanya guru bertanya : Siapa yang bisa menjawab? maka hampir semua anak angkat tangan sambil meloncat kegirangan dari tempat duduknya dengan mengatakan "saya tau pak/bu" lalu sang guru menyebut namanya, saat disebut nama dirinya tumbuhlah rasa percaya diri dalam hatinya maka dengan penuh keyakinan sang anak menjawab pertanyaan tersebut, lalu apa yang terjadi kalau tiba-tiba gurunya berkata, "bukan.... , itu salah" sejak itulah sang anak bisa mengalami rasa minder dan bersalah sehingga agak susah merangsang kembali potensi dirinya, apalagi yang dikatakatan gurunya adalah "goblok.... kamu bodoh tolol atau sejenisnya hasilnya dapat dibayangkan kalau lebih para dari trauma.

Guru adalah pemimpin dikelas, seharusnya mereka yang pesimis buatlah optimis, mereka yang minder buatlah teggar, mereka yang trauma jadikan move on, yang pemalu silahkan dipandu, yang penakut jadikan pemberani, dan yang putus asa silahkan motivasi. Guru yang bisa melaksanakan semua ini berarti pemimpin dimasa depan. Hanya mereka yang bertindak dengan sikap mentalitas positif yang dapat menjadi 
pemimpin ${ }^{23}$. Lalu apa upaya pemangku kebijakan dan kepentingan dalam memotivasi dan mewujudkan guru handal, tenang mengajar, lebih bershabat dengan siswa, memahami potensi dan latar belakang siswa? Apa cukup dengan iming iming tunjanga profesi yang polemik sana sini?, saatnya perlu digalakkan program merdeka belajar dan merdeka mengajar tanpa ada tendensi kebijakan.

\section{Kontaminasi 'Virus' globalisasi era disrupsi}

Kita sadar bahwa dunia saat ini terkontaminasi oleh dampak kemajuan teknologi komunikasi dan informasi sehingga terjadi arus interaksi sosial secara cepat dalam semua sektor tidak terkecuali sektor pendidikan. Gelombang globalisasi disatu sisi membawa manfaat bagi manusia tetapi juga berdampak pada timbulnya banyak mudharat. Globalisasi telah mengubah paradigm dan tatanan dalam beberapa aspek kehidupan, baik pendidikan, ekonomi, politik, sosial dan budaya. ${ }^{24}$ Jiwa dan karakter para pendidik dibayang-bayangi model dan gaya hidup milenial yang banyak menuntut material, akibatnya 'para pahlawan tanpa tanda jasa' semakin mengalami problematika ganda dalam realitas kehidupan saat ini. Era dimana pengaruh revolusi industri keempat semakin mengubah tatanan tradisional menjadi tatanan serba mesin canggih. ${ }^{25}$

Penguatan karakter siswa memang penting, yang lebih penting aalah mendahulukan karakter guru. agar guru bisa membangun karakter siswa secara tepat. Bagaimana guru bisa membangun karakter siswa, sementara karakter dirinya masih belum stabil?.

\footnotetext{
${ }^{23}$ M Hariwijaya, Menjadi Diri Sendiri, guna meraih puncak prestasi strategi membangun citra diri, (Jakarta : oryza, 2011), 25.

${ }^{24}$ Oviyanti, Fitri. "Tantangan pengembangan pendidikan keguruan di era global." Nadwa 7.2 (2016): 267-282.

${ }^{25}$ Rahmawati, Fitri. "Kecenderungan Pergeseran Pendidikan Agama Islam di Indonesia Pada Era Disrupsi." TADRIS: Jurnal Pendidikan Islam 13.2 (2018): 244-257.
} 
Posisi guru dalam dunia pembelajaran sangat urgen, boleh dikata, guru adalah faktor penentu keberhasilan proses pembelajaran yang berkualitas, berhasil tidaknya pendidikan mencapai tujuannya selalu dihubungkan dengan kiprah para guru. Oleh karena itu, usaha usaha yang dilakukan dalam meningkatkan mutu pendidikan hendaknya dimulai dari peningkatan kualitas guru ${ }^{26}$. Sementara itu kewajiban utama yang harus dijalankan oleh para orang tua, ulama, pendidik, dan para pemimpin adalah untuk melestarikan dan mengajarkan nilai-nilai moral kepada anak anak (generasi penerus bangsa). Nilai nilai moral yang dilatihkan dan dididikkan pada anak anak ini akan membentuk karakter dan akhlak mulia27.

Disamping karakter guru yang kokoh dan kuat guru perlu berinovasi dengan berbagai metode pembelajaran salah satu yang diajarkan dalam islam adalah metode teladan seperti dakwahnya Rasulullah SAW. Pembelajaran keteladanan merupakan metode langsung yang dipraktikkan oleh guru. Melalui contoh-contoh yang tepat, maka anak akan meniru apa yang dicontohkan, anak merupakan peniru yang baik apapun yang dilihat dan didengar oleh anak dari orang orang dewasa, maka itu akan diikuti28. Dalam menghadapi krisis global disektor pendidikan pola pikir dan perilaku manusia, termasuk guru dapat diasumsikan pada tiga kelompok:

Pertama, ada yang hanyut dalam perubahan global di berbagai sektor kehidupan termasuk pendidikan. Karenanya, pola pikir manusia sudah dipengaruhi oleh kekuatan materialistik meninggalkan spritualistik dan moralitas, materialistik mengajak pola pikir mereka pada bagaimana mendapatkan harta yang mudah, banyak dan segala

\footnotetext{
${ }^{26}$ Lihat Sitiatava Rizema Putra, Metode Pengajaran Rasulullah SAW, (Yogyakarta : Diva Press, 2016), 26.

${ }^{27}$ Lihat Moh Said, Pendidikan Karakter di Sekolah, (Surabaya ; Jaring pena, 2011), 81.

${ }^{28}$ Lihat Najib Sulhan, Guru yang berhati guru, mendidik dengan inspirasi al-Quran, mengajar dengan hati untuk Indonesia Cerdas, (Jakarta : Dikrul Hakim, 2016),167.
} 
aktifitasnya selalu diukur dengan harta sementara mereka tidak pernah memperhitungkan aspek spritualitas yang lebih mengedepankan keyakinan, ketenangan, dan kedamaian, bahkan aspek moralitas yang bersentuhan langsung dengan masyarakat juga sudah mulai kurang diperhatikan akibatnya muncullah para koruptor dari kaum terdidik dan terhormat. Dengan demikian, globalisasi bermakna hilangnya identitas diri dalam bermasyarakat, berbangsa, dan bernegara, bahkan bisa jadi jika dibiarkan akan terjadi hilangnya harga diri. Guru yang mengedepankan aspek spritualitas akan merasakan ketenangan mengajar, mereka yang memiliki moralitas akan menemukan kedamaian diberbagai lingkungan lebih lebih dilingkungan pendidikan.

Kedua, dalam kasus globalisasi ada yang bersikap extrim dengan mengharamkan secara totalitas terhadap segala bentuk perubahan yang ditimbulkan, mereka hanya memandang satu sisi saja yaitu akibat nigatif dari proses, andaikan ada orang bersalah karena mencuri mereka menjustifikasi sebagai pencuri, tanpa melihat penyebabnya dan dianggap sebagai watak atau tabiat yang dimiliki sebagai pencuri, seolah olah sudah tidak ada kebaikan didalam hatinya, padahal hakekatnya semua manusia di dunia ini ingin baik tetapi karena terpaksa ia berbuat walaupun bertentangan dengan hati nuraninya, seharusnya diklarifikasi terlebih dulu kenapa ia mencuri? Karena terpaksa atau memang sudah profesinya. Guru di era milenial seharusnya mampu memanfaatkan potensi potensi arus percepatan belajar siswa melalui kecanggihan tehnologi bukan malah anti dan memaki maki dampak globalisasi.

Ketiga, kelompok yang terahir ini mungkin yang lebih bijaksana, mereka mengambil sikap menerima dengan men-filter segala wujud perubahan globalisasi melalui prinsip relegius, prinsip ini menjadi modal utama masyarakat Indonesia dalam menyikapi arus globalisasi 
yang semakin tidak bisa dibendung, peran agama menjadi sangat penting bagi anak yang ditanamkan di lingkungan keluarga, di lingkungan sekolah, dan di lingkungan masyarakat sebab lingkungan agamis secara spontan akan mengajak anak untuk patuh dan taat berbuat baik serta menyenangi hal-hal positif bagi dirinya sendiri. Disisi lain mereka memiliki prinsip historis yang esensi-nya bahwa dalam catatan sejarah bangsa Indoensia memiliki budaya luhur yang mengedepankan etika sosial yang humanis, bagaimana mereka menghormati budaya? bagaimana mereka menghargai dirinya sendiri? Dan bagaimana mereka menghargai orang lain?.

Sebagai makhluk sosial mereka telah mewarisi budaya luhur menghormati orang lain dalam berbagai interaksi sosial dan tidak beranggapan hanya dirinyalah yang benar, mereka berkeyakinan esensi kehidupan adalah kebaikan, hal yang baik untuk tujuan kebaikan akan menghasilkan kebaikan pula, hal yang jelek kalau untuk tujuan kebaikan akan dapat mengantarkan pada kebaikan, sebaliknya juga demikian, hal yang baik sekalipun kalau untuk tujuan kejelekan akan berakibat pada kejelekan. Orang yang berbuat baik dibalas dengan kebaikan itu sudah biasa, tetapi yang tidak biasa apabila kebaikan dibalas dengan kejelekan kalau kejelekan dibalas dengan kejelekan sudah biasa, namun yang tidak biasa adalah apabila kejelekan dibalas dengan kebaikan. Intinya memandang baik dan jelek harus dari sisi proses dan hasil. Taruhkan sebagai contoh handphone sebagai dampak globalisasi bisa digunakan untuk hal positif juga bisa untuk hal negatif tergantung pengguna maunya apa? Nah tugas kita adalah bagaiman menfilter kemauan anak anak bangsa melalui prinsip pendidikan relegius, historis, dan filosofis sebagai ikhtiyar melahirkan kesadaran diri dari kekuatan negatif thingking arus globalisasi yang merongrong pola pikir positif melalui proses pendidikan yang bermartabat (progressive education). 


\section{Kesimpulan}

Pendidikan berarti upaya transformasi ilmu pengetahuan (transfer of knowledge), pengayaan nilai (transfer of value), pengetahuan tentang karakter kebudayaan (transfer of culture), dan penanaman nilai keagamaan (transfer of religius) yang diarahkan pada upaya untuk "memanusiakan manusia". Upaya seperti itulah hakikat pendidikan, yaitu berorientasi pola perubahan perilaku individu agar memiliki nilai-nilai luhur, cerdas dan terampil.

Al-hasil, hakikat pendidikan yang memanusiakan manusia dapat dirumuskan dalam lima domain: pertama; pendidikan sebagai proses interaksi manusiawi yang seimbang antara kedaulatan anak didik dengan pendidik. kedua; Pendidikan merupakan usaha regeneration anak didik untuk menghadapi lingkungan yang selalu mengalami perubahan. ketiga; Pendidikan meningkatkan kualitas kehidupan pribadi masyarakat. Keempat; pendidikan berlangsung seumur hidup. Kelima; pendidikan merupakan kiat dalam menerapkan prinsip-prinsip keilmuan dan teknologi.

\section{Daftar Pustaka}

Akbar, K. Setiawan, 2011, Integrasi Pendidika Karakter dalam pembelajaran berbasis intercultural, Jurnal Pendidikan Karakter, Tahun 1, Nomor 1, Oktober, 110-118.

Akmal, Mundiri dan Zahra, Irma. 2017. "Corak Representasi Identitas Ustadz dalam Proses Transmisi Pendidikan Karakter di Pesantren." Jurnal Pendidikan Islam Indonesia 2.1: 21-35.

Al-Qur'an ..Q.S. 16:112

Al-Qur'an..Q.S. 4:75; 7:4; dan 17;16.

Darmaji dkk., 2020. Sistem Penjaminan Mutu Internal Sekolah di Satuan pendidikan Dasar, JPDN: Jurnal Pendidikan Dasar Nusantara, $\begin{array}{lllll}\text { Volume } & 5 & \text { Nomor } & 2, & \text { Januari }\end{array}$ ttps://doi.org/10.29407/jpdn.v5i2.13190 
Kusuma, Asri dan Dewanti. 2020. "Roadmap atau Blue Print Pendidikan Nasional." Arsip Publikasi Ilmiah Biro Administrasi Akademik, 2020.

Komisi Informasi Pusat Republik Indonesia, UU Nomor 20 Tahun 2003 tentang Sistem Pendidikan nasional, https://komisiinformasi.go.id/?p=1638 (diakses 01 Maret 2020)

Lestari, Ali. 2011. Pandangan Islam tentang factor pembawaan dan Lingkungan dalam pembentukan Manusia; kajian ilmu pendidikan islam, Jurnal Pendidikan UNIGA, Volume 5, Nomor 1.

Mahsun, M., \& Koiriyah, M. 2019. Meningkatkan Keterampilan Membaca Melalui Media Big Book Pada Siswa Kelas Ia Mi Nurul Islam Kalibendo Pasirian Lumajang. Bidayatuna: Jurnal Pendidikan Guru Mandrasah Ibtidaiyah, 2(01), 60-78. http:// ejournal.iaisyarifuddin.ac.id/index.php/bidayatuna/article $\angle$ view/361

Mashuri, S. 2007. Transformasi Tradisi Keilmuan Dalam Islam: Melacak Akar Kemunculan Dan Perkembangan Institusi Pendidikan Islam. HUNAFA: Jurnal Studia Islamika, 4(3), 227-236. https://doi.org/https://doi.org/10.24239/jsi.v4i3.215.227-236

Mundiri, Akmal dan bariroh, Afidatul. 2018. Amplifikasi Profesi Guru dalam Proses Pendidikan Transformatif Perspektif Al-Ghazali, Jurnal Ilmiah Islam Futura, Vol. 18, No.1, Agustus.

Nata, Abuddin. 1997. Filsafat Pendidikan Islam (Ciputat: PT Logos Wacana Ilmu), 112

Hartomo. 2013. Manajemen potensi diri, membangun motivasi dan mencetak prestasi unggul, kreatif, inovatif, dan produktif, ttp: Platinum, 52.

Hariwijaya, M. 2011. Menjadi Diri Sendiri, guna meraih puncak prestasi strategi membangun citra diri, Jakarta : oryza, 25.

Junaedi, Mahfud, 2017, Paradigma Baru Filsafat Pendidikan Islam, Depok: Kencana, cetakan ke-1, 93

Oviyanti, Fitri. 2016, "Tantangan pengembangan pendidikan keguruan di era global." Nadwa 7.2 : 267-282.

Putra, Sitiatava Rizema, 2016, Metode Pengajaran Rasulullah SAW, Yogyakarta:Diva Press, 26. 
Rahmawati, Fitri. 2018. "Kecenderungan Pergeseran Pendidikan Agama Islam di Indonesia Pada Era Disrupsi." TADRIS: Jurnal Pendidikan Islam 13.2 : 244-257.

Said, Moh. 2011. Pendidikan Karakter di Sekolah, Surabaya:Jaring pena, 81.

Sirozi, M. 2005. Politik Pendidikan, Jakarta : PT Raja Grafindo Persada, 220

Saryono, Djoko. 2017. "Kaum Muda, Pembentukan Karakter dan Intelektualitas, dan Peran Budaya Lokal pada Abad Pengetahuan." Journal of Intensive Studies on Language, Literature, Art, and Culture, 2017, Dari International Proceedings; International Seminar on Language, Literature, Art and Culture (ISLLAC), Malang, September 26-27.

Suharyo dan Soejitno Irmim, 7 Langkah memperbaiki diri, pedoman efektif untuk memperbaiki perilaku menuju kesempurnaan diri (ttp : Syima Media, tt), 69.

Sulhan, Najib. 2016. Guru yang berhati guru, mendidik dengan inspirasi alQuran, mengajar dengan hati untuk Indonesia Cerdas, (Jakarta : Dikrul Hakim), 167.

Sulhan, Najib. 2011. Panduan praktis Pengembangan Karakter dan Budaya Bangsa, sinergi sekolah dengan rumah, Surabaya : Jaring Pena, 28.

Suparlan, Henricus. 2015. "Filsafat pendidikan Ki Hadjar Dewantara dan sumbangannya bagi pendidikan indonesia." Jurnal Filsafat 25.1 : 5674 .

Yulius, Mellky. 2020, "Strategi Meningkatkan Mutu Pendidikan Melalui Manajemen Sarana Dan Prasarana Pada Smk Negeri 1 Singkawang." KHAZANAH PENDIDIKAN 13.2. 